\title{
THE MECHANISM OF COMMUNITY LED LOCAL DEVELOPMENT IN ROMANIAN URBAN AREAS
}

\author{
Andreea PUȘCAȘa*, Ioana BELEIU ${ }^{\mathrm{b}}$ \\ a) University of Agricultural Sciences and Veterinary Medicine, Faculty of Food \\ Science and Technology, Cluj-Napoca, Romania \\ b) Babeș-Bolyai University, Faculty of Economics and Business Administration, \\ Cluj-Napoca, Romania
}

Please cite this article as:

Pușcaş, A. and Beleiu, I., 2020. The mechanism of community led local development in Romanian urban areas. Review of Economic Studies and Research Virgil Madgearu, 13(2), pp.129-146.

doi: 10.24193/RVM.2020.13.65.
Article History:

Received: 5 August 2020 Accepted: 24 October 2020

\begin{abstract}
Community led local development (CLLD) is a tool of the European Commission, used for territorial development. Local Action Groups were funded in the rural areas of Romania, since the 2007-2013 programming period through LEADER, demonstrating positive effects in terms of social innovation and disproof of social disparities. In urban areas, CLLD is a recent multi-fund approach, financed by the European Social Fund (ESF) and the European Regional Development Fund $(E R D F)$. Despite the intentions addressed for simplifying the implementation of the mechanism by the Romanian authorities, several challenges and delays however occurred. The present research reveals the similarities and the main differences between the implementation of the mechanism, in urban and rural areasesides, it proposes a set of recommendations to increase the efficiency of the studied mechanism, based on a case study on the implementation of the CLLD mechanism in Gherla, Romania.
\end{abstract}

Key words: community; development; local action group; European funds JEL Classification: $R 11 ; R_{58}$

(C) 2020 Alma Mater Publishing House. All rights reserved.

* Corresponding author. E-mail address: andreea.puscas@usamvcluj.ro. 


\section{References:}

1. Anton, S.; Corad, I.B.; Iamandi Cioinaru, E.C.; Man, T.C.; Moldovan, S.C.; Neculau, G.; Stanculescu, M.S.; Swinkels, R.A. and Trocea, A., 2014. Integration strategies for urban poor areas and disadvantaged communities : integrated intervention tool: Strategii de integrare a comunitatilor urbane marginalizate: instrument de interventie integrata (Romanian). Integration strategies for urban marginalized communities Washington, D.C.: World Bank Group. [online] Available at: <http://documents.worldbank.org/curated/ en/189131468144559267/Strategii-de-integrare-a-comunitatilorurbane-marginalizate-instrument-de-interventie-integrata> [Accessed 13 September 2020].

2. Buda, D., 2019. Funds Synergy-A Model for Sustainable Development of the Administrative Territorial Units in Romania. In C. Haruța, C.M. Hințea, O. Moldovan, eds. 2019. Sustainable Development and Resilience of Local Communities and Public Sector Organizations. Cluj-Napoca: Accent, pp.88-99.

3. Cocoşatu, C.C., 2015. Abordare sistemică privind implementarea fondurilor externe nerambursabile în România (Systemic Approach on the Implementation of European Grants in Romania). Impactul transformărilor socio-economice și tehnologice la nivel national, european si mondial, 1, [online] Available at: <https://ssrn.com/ abstract $=2619223>$ [Accessed 13 June 2020].

4. European Commission, 2013. Regulation No. 1303/2013 of the European Parliament and of the Council of 17 December 2013, [online] Available at: <https://eur-lex.europa.eu/legal-content/ EN/TXT/?uri=CELEX:32013R1303> [Accessed 20 June 2020].

5. European Commission, 2019. European Commission Country Report Romania 2019 Including an In-Depth Review on the prevention and correction of macroeconomic imbalances, [online] Available at: <https://ec.europa.eu/info/sites/info/files/file_ import/2019-european-semester-country-report-romania_en.pdf> [Accessed 15 June 2020].

6. Gherla Municipality, 2017. The Strategy of local development: Get involved in the present! Change the Future! of Gherla Municipality, Gherla, Romania, [online] Available at: <http://plaiurisomesene. 
Pușcaș, Beleiu, The Mechanism of Community Led local Development...

ro/wp-content/uploads/2019/o5/1.-SDL-rectificat.pdf> [Accessed 3 July 2020].

7. Lucian, P., 2014. Absorption of European funds by Romania. Procedia Economics and Finance, 16, pp.553-556.

8. Marquardt, D., Möllers, J. and Buchenrieder, G, 2012. Social networks and rural development: LEADER in Romania. Sociologia Ruralis, 52(4), pp: 398-431.

9. Ministry of Agriculture and Rural Development, 2018. Guide of Local Action Groups for the Implementation of Local Development Strategies, version 4, Romania, [online] Available at: <https://www. madr.ro/docs/dezvoltare-rurala/Axa_LEADER/2014-2020/2018/ ghid-GAL/versiunea-04/Ghid-GAL-pentru-implementarea-SDLversiunea-04.pdf $>$ [Accessed 7 June 2020].

10. Ministry of European Funds, 2014. Romanian partnership agreement for the 2014-2020 programming period, Romania, [online] Available at: <https://www.fonduri-structurale.ro/Document_Files/ Stiri/ oo014830/sfvjd_Acord\%20de\%20parteneriat\%20oficial.pdf> [Accessed 17 May 2020].

11. Ministry of European Funds, 2017. Specific guide on the submission and selection of Local Development Strategies, Stage II of the DLRC mechanism, Romania, [online] Available at: <https:// www.finantare.ro/ghidul-specific-privind-depunerea-si-selectiastrategiilor-de-dezvoltare-locala-etapa-a-ii-a-mecanismului-dlrc. html $>$ [Accessed 2 September 2020].

12. Ministry of European Funds, 2019a. Specific guide for funding applications related to the project files selected by the LAG under the SDL - Stage III of the DLRC AP 5 / PI mechanism 9.vi/ OS 5.1, Romania, [online] Available at: <http://mfe.gov.ro/wp-content/ uploads/2019/o9/a9f891ec514ae1794c8d2ed6ef127149-1.zip> [Accessed 14 May 2020].

13. Ministry of European Funds, 2019b. Guidelines for local action groups on the implementation of local development strategies at the level of cities with over 20,00O inhabitants - Stage III of the DLRC mechanism, Romania, [online] Available at: <https://www. fonduri-ue.ro/images/files/programe/CU/POCU-2014/2019/15.04/ Orientari_GAL_etapa_III_CLLD.pdf $>$ [Accessed 3 June 2020].

14. Ministry of European Funds, 2019c. Specific guide - specific conditions for accessing funds in project calls ROP/ 2019/9 /9.1/1/7region, ROP/2019/9/9.1/1/bi and ROP/ 2019/9/9.1/1/ 
Enterprises, Priority Axis 9 - Supporting the economic and social regeneration of disadvantaged communities in the urban environment, Investment priority 9.1 - local development under the responsibility of the community (DLRC), Romania, [online] Available at: <http://www.inforegio.ro/ro/axa-prioritara-9/ apeluri-lansate/787-axa-prioritara-9-sprijinirea-regenerariieconomice-si-sociale-a-comunitatilor-defavorizate-din-mediulurban-prioritatea-de-investitii-9-1-dezvoltare-locala-subresponsabilitatea-comunitatii-dlrc > [Accessed 23 June 2020].

15. Olar, A. and Jitea, I. M., 2020. Assessing the quality of the local development strategies in Romania, evidence from 2014-2020 programming period. Scientific Papers: Management, Economic Engineering in Agriculture \& Rural Development, 20(2), pp.347-357.

16. Petrescu, C., 2015. Association and cooperation in Romanian rural areas-the LEADER experience. Jurnalul Practicilor Comunitare Pozitive, 15(2), pp.28-42.

17. Pocol, C. B. and Kassai, Z., 2016. Initiatives for promoting innovation among Local Action Groups in Romania. Bulletin of University of Agricultural Sciences and Veterinary Medicine Cluj-Napoca, Horticulture, 73(2), pp.291-298.

18. Servillo, L. and De Bruijn, M., 2018. From LEADER to CLLD: The adoption of the new fund opportunities and of their local development options. European Structural and Investment Funds Journal, 3, pp. 223-233.

19. Tesliuc, E.D., Grigoras, V.A. and Stanculescu, M.S., 2015. Background study for the national strategy on social inclusion and poverty reduction: 2015-202O. World Bank, Bucharest, [online] Available at: <https://openknowledge.worldbank.org/bitstream/ handle/10986/23830/Backgroundostuoeductionoo0201502020. pdf? sequence $=1$ \&isAllowed $=\mathrm{y}>$ [Accessed 13 June 2020].

20. The European Evaluation Helpdesk for Rural Development, 2017. Evaluation of LEADER/CLLD, [online] Available at: <https://enrd. ec.europa.eu/sites/enrd/files/evaluation_publications/twg-03leader_clld-aug2017.pdf > [Accessed 24 July 2020].

21. Volk, A. and Bojnec, S., 2014. Local action groups and the LEADER co-financing of rural development projects in Slovenia. Agricultural Economics, 60, pp.364-375. 